\title{
Towards Solutions for State vs. Local Community Conflicts Over Forestland: The Impact of Formal Recognition of User Rights in Krui, Sumatra, Indonesia
}

\author{
Koen Kusters • Hubert de Foresta • Andree Ekadinata • \\ Meine van Noordwijk
}

Published online: 14 February 2007

(C) Springer Science + Business Media, LLC 2007

\begin{abstract}
In 1998, a decree issued by the Indonesian government enabled communities in Krui, Indonesia, to register for concession rights over the area of state forest land planted with their agroforests. Registration would provide farmers with the legal right to manage and benefit from these agroforests. In 2005, we found that even though none of the Krui communities has ever formally applied for their concession rights, the decree has been instrumental in stopping outsiders' attempts to appropriate these agroforests. Farmers within the state forest zone felt secure enough to continue investing in their complex agroforestry systems, while planting trees reinforced their feeling of security. We conclude that it is not the legal status of tenure, but the perception of tenure security that is of significance in people's land-use decisions. These results are considered in the wider context of state-community conflicts over forest land in the tropics.
\end{abstract}

K. Kusters $(\square)$

Universiteit van Amsterdam,

Amsterdam, The Netherlands

e-mail: k.kusters@uva.nl

K. Kusters

Center for International Forestry Research,

Bogor, Indonesia

H. de Foresta

Institut de recherche pour le Développement (IRD),

Botany and Computational Plant Architecture (UMR AMAP),

Montpellier, France

A. Ekadinata $\cdot$ M. van Noordwijk

World Agroforestry Centre (ICRAF),

Southeast Asia Regional Office,

Bogor, Indonesia
Key words Tenure $\cdot$ security $\cdot$ property rights $\cdot$ user rights . agroforestry $\cdot$ deforestation

\section{Introduction}

The planted agroforests in the Krui region, on the southwest coast of Sumatra, have been subject to dispute over tenure. In 1998 the Indonesian Minister of Forestry issued a decree that designated a part of the state forest area a special zone for agroforestry. The decree enabled Krui communities to apply for legal user rights (termed 'concession rights' in the decree) for the agroforests located within this zone. At the time, this decree was considered a 'breakthrough' in Indonesian forest policy (Fay et al., 1998). By 2005, none of the communities had applied for their concession rights, but local perceptions of tenure security were at their highest since the 1980s. The analysis of this somewhat paradoxical situation serves here as the basis for a discussion of the relation between the legal component of tenure security and the sustainability of managed forest systems.

Tenure security does not inevitably lead to a sustainable use of land and natural resources - it is indeed compatible with any type of use, including those that are unsustainable (Acheson, 2000; Fearnside, 2001). However, even though the effects of secure tenure on forest clearance seem to differ from place to place (see Godoy et al., 1998 for overview of literature), such security is widely recognized as one of the major pre-conditions for the sustainable development of tree-based and forest systems which require long-term investments (Schlager and Ostrom, 1992; Suyanto et al., 2001; White and Martin, 2002; Enters et al., 2003; Pagdee et al., 2006). 
In many tropical countries, governments have set aside large areas of their national territory as state forest (FAO, 2005), with little regard for rural populations living in these areas (Fay and Michon, 2005), so that local land use frequently violates the national legal framework. Equally the state's legal framework is frequently at odds with local traditions and rights, and with the history of legal pluralism (Lynch and Talbott, 1995; Safitri, 2005). National laws and regulations are most often known locally only by government representatives and forest agents dealing with communities using these contested areas. These agents usually have nothing to gain in confronting locals when nothing other than respect of the top-down concept of state land ownership is at stake. In such situations most locals ignore the contested status of the land so that it may have little impact on their perception of land tenure security. However, when government supported projects claim land already controlled by local communities, the potential for conflict is highlighted and this inevitably leads to a growing feeling of insecurity regarding land tenure. When locals have developed agroforestry systems, that insecurity directly threatens the continuation of their long term investment in tree and soil management, with far-reaching impacts on the sustainability of their land-use system (Pagdee et al., 2006). The contradictions between the national legal framework and local use in forest areas, and their possible impact on sustainable development have been increasingly recognized by researchers (Fay and de Foresta, 2001; Brasselle et al., 2002; Fay and Michon, 2005).

Conflicts between states and communities over forest lands, and their attempted resolutions are not new. In England, the Magna Carta was signed and sealed by King Henry II in 1215 as a concession to the nobility's demands, among others, that control over the royal hunting domain was returned to local communities. In the last few decades several countries have developed legal instruments to grant rights over forest resources to local communities. Wellknown examples are the Certificates of Ancestral Domain Claim (CADC) in the Philippines (Lynch and Talbott, 1995), the extractive reserves in Brazil (Fearnside, 1989; Peralta and Mather, 2000), and the Joint Forest Management schemes in India (Kumar, 2002). Such tenure arrangements are generally expected to promote sustainable forest management while enabling local communities to capitalize on available resources. White and Martin (2002) estimate that $22 \%$ of the forests in developing countries are currently reserved for or owned by community and indigenous groups, acknowledging the fundamental difference between 'reserved for' and 'owned by,' since the former often does not imply a transfer of decision making power over land use.

State-community conflicts may arise when the state claims a territory where local communities have developed longstanding tree-based systems. The first step in devising solutions to such conflicts would be official state recognition of local rights to both the land and the tree-based systems developed on it (Michon and De Foresta, 1999; Fay and Michon, 2005; Michon, 2005; Tomich et al., 2004). The subsequent development of specific solutions will depend on the national and local political and policy context as well as on the ecological conditions of the contested areas and the services expected by the government for those areas. Options range from the extreme of compensating local communities for their foregone opportunities to the extreme of excluding contested areas from the state forest domain, through many forms of intermediate options.

This paper reports on such an intermediate tenure arrangement in Indonesia, one of the most populated countries in the world with almost $70 \%$ of its land base classified as state forest domain (Forestry Planning Agency $2004 \mathrm{a}$ and b). The tenure arrangement is known as the Kawasan dengan Tujuan Istimewa-Krui (KdTI-Krui) decree-_Zone with Distinct Purpose-Krui.' We first describe the decree and the local context in Krui, Sumatra. We then raise the specific questions that guided our analysis of the impact of the decree and present the methods used and the results. In the final part we discuss the role the decree played in ensuring the continuation of the original land-use system developed by local farmers, and we discuss the legal component of tenure security in a broader context. We also briefly address the future threats and opportunities related to the local tenure arrangement in Krui and reflect on the KdTI decree as a possible solution to similar statecommunity conflicts in other countries.

\section{The Krui Context and the KdTI-Krui Decree}

Located at the south-western tip of the large island of Sumatra, between the Bukit Barisan Selatan (BBS) National Park to the east and the Indian Ocean to the west, the Krui region in the West Lampung district is internationally famous for its land-use system, known as damar agroforests (Michon et al., 2000). Damar is the generic Indonesian term for resin of various botanical origins. The tree species Shorea javanica yields the most valuable type of resin, known as cat eye resin or damar mata kucing, and naturally occurs at low density in the forests of West Lampung. The resin is used and commercialized for the creation of products including incense, varnish, paint, and cosmetics. Local farmers in the Krui region domesticated this resin-producing tree more than a century ago (De Foresta and Boer, 2000).

Compared with other tree based agricultural systems, damar agroforests are relatively close to natural forests in 
terms of structure, function, dynamics and diversity (Michon and De Foresta, 1995). A damar agroforest develops by plant succession in which stages are planned and managed by farmers to fulfil their own economic needs. It begins as a swidden, with rain-fed rice and vegetables as the first productive stage, while coffee, pepper vines and tree species (damar, fruit trees, timber trees and dedicated shade trees) are planted. The coffee and pepper constitute the second productive stage of the agroforest. The third stage, the mature agroforest, becomes productive about 20 years after planting. This last stage ensures a permanent tree cover that will soon mimic a 'natural' forest of high stature with a canopy reaching $40 \mathrm{~m}$, a multistrata structure and a high diversity in forest plants and animals (Michon et al., 2000). ${ }^{1}$ Damar trees can remain productive for 50-80 years. Farmers replace these and other tree species in the agroforest one by one, using both natural regeneration and enrichment planting.

The process of converting parts of local territories to damar agroforest has been occurring since the 1880 s, mostly without external support. Mature damar agroforests appear as large forest massifs, covering a total area that was estimated to be about 50,000 ha in 1995 , and producing more than $80 \%$ of the world's damar mata kucing. In line with their swidden origin, these agroforests are made up of a juxtaposition of individually owned and individually managed plots, with some resources such as fuelwood or fruit for direct consumption being accessible to anyone in the community (Michon et al., 2000).

The Krui area consists of 16 traditional territories, locally referred to as marga. Each traditional territory consists of several communities and has clear territorial boundaries. Under the Dutch rule the government negotiated the boundaries of a Forest Reserve with the marga leaders in the 1930s. The land from the coast up to the Reserve was left under customary regulation and the Krui communities accepted the boundaries. In 1991, under the rule of President Suharto, the Reserve officially became a National Park, but this did not effectively change the related restrictions for local communities. In the same year, however, the state also extended the boundaries of the state forest land beyond the boundaries of the National Park. The expansion of state land happened not only without consulting the marga leaders, who had lost almost all their representative power, but also without checking in the field the land-use changes that had occurred in the area since the 1930s. The expansion of state land was part of a national policy to secure access to the revenue of forests for the state

\footnotetext{
${ }^{1}$ Once a coffee-pepper plantation has been established, the additional cost for establishing what will become the damar agroforest (damar and fruit tree seedlings) is very low. Planting trees in a coffee plantation system is thus a low-cost long-term investment.
}

and its designated 'concessionaires,' which resulted in the classification of more than $70 \%$ of Indonesia as state forest zone (Fay and Michon, 2005). The government classified a significant part of the traditional territories of the Krui region, between the National Park and the new boundaries of the state forest land, as State Production Forest (HPT) and a small part as Protective Forest (HL). The HPT designation implies that local use is strongly restricted (de facto prohibited) and that the government may issue logging concessions (with some restrictions). The local communities were never formally informed and in the political context of the time the state was able, at least on official maps, to enforce its claims.

After the damar agroforests were "rediscovered" formal science (Torquebiau, 1984; Mary and Michon, 1987) long-term research analyzed the social, economic and ecological aspects of this land use (e.g., Lubis, 1996; Michon et al., 2000; Wollenberg and Nawir, 2005). The contested status of the land soon became a priority issue because of the risks this entailed for local communities and their agroforests, especially the risk that agroforests would be transformed into logging concessions or converted to tree-crop plantations by outsiders. A consortium of NonGovernmental Organizations (NGOs) and research organizations, known as Tim Krui, became actively involved in gaining high-level policy attention for the mismatch between the classification as 'natural forest' and the fact that the damar gardens were planted and managed by local farmers. In 1997 Tim Krui organized a discussion involving community representatives, NGOs, research institutes and government officials of all levels. Then, after a complex process of negotiations involving the district, provincial and national level forest authorities, Indonesia's Minister of Forestry signed the KdTI-Krui decree in January 1998. The decree designated 29,000 ha of damar agroforest (in various stages of development) that were already established on HPT/HL lands as 'KdTI-area' and acknowledged local people as the only beneficiaries of the management of that area. The decree did not however, automatically result in a change of legal status, as communities with agroforest within the designated zone would have to apply formally for official registration of concession rights. In the KdTI area, farmers would be allowed to harvest damar resin for commercial purposes, to cut unproductive damar trees, to cut trees hampering the growth of damar or of other useful tree species, to replant damar trees and other useful tree species, to harvest naturally fallen timber trees and to plant and collect non-timber forest products. In turn the commu-

\footnotetext{
${ }^{2}$ There had been various reports in the Dutch literature of the 1930s, see abstracts from F.W. Rappard and Oesman Nandika in Van Goor and Kartasubrata 1982.
} 
nity has to maintain tree stands both in the damar agroforest area as well as in its surroundings, and pay tax on timber and other products that are extracted for commercial purposes (MoF, 1998). Even though the KdTI area is still part of the state forest zone, the decree was welcomed as a 'breakthrough' as it was the first time the Indonesian government had acknowledged local user rights on state forest land (Fay et al., 1998).

The rationale of the Ministry of Forestry was to provide security for farmers as a necessary condition for the continuation of agroforestry activities in the area $(\mathrm{MoF}$, 1998). Implicitly, by maintaining the agroforest zone, the decree was also meant to help protect the neighbouring National Park from encroachment.

The decree has influenced the thinking about forest regulation in Indonesia (Fay et al., 1998; Michon et al., 2000; Sirait et al., 2001) but its impacts on the ground have so far not been evaluated. We set out to explore the following questions:

(1) Do farmers effectively maintain the damar agroforest area?

(2) Is there a relationship between the occurrence of damar agroforest and deforestation in the adjacent National Park?

(3) Is the decree that recognizes farmers' use rights known to the farmers, local government and forestry officials and is it being implemented?

(4) Is there any evidence that the decree has modified land use in the area?

\section{Materials and Methods}

To analyze land-cover dynamics we used Landsat images from 1997 and 2002. The images encompass 480,000 ha of land in the southeast of Sumatra, covering about $14 \%$ of Lampung province and $70 \%$ of Bukit Barisan Selatan (BBS) National Park, the third largest National Park in Sumatra. The area covered by the satellite images (Fig. 1) forms the study area for the land-cover analysis presented in this article. We assessed land-cover changes within the National Park boundaries, the Krui region, and the KdTI area in particular. The Krui region refers to the area of approximately 106,000 ha that is locked in between the National Park and the Indian Ocean. The KdTI area, as defined on a map produced by the Indonesian Department of Forestry in 1998, totals about 29,000 ha and is located southwest of the National Park. The different land-cover types were classified using a hierarchical classification system. We conducted land-cover change analysis using the post classification comparison method. We could not conduct a proper assessment of the accuracy of our land cover classifications due to the lack of reference information from 1997 and 2002, and the results of the land cover change analysis are therefore estimations. ${ }^{3}$ For a more detailed description of the methodology see Ekadinata et al. (2005).

During field study from January to June 2005 we collected information on farmers' perceptions of tenure security and the KdTI decree. As part of a wider study on livelihood dynamics we surveyed a total of 296 households - a random sample of $25-30 \%$ of the households in three research villages. ${ }^{4}$ The household survey was mainly focussed on income (not discussed in this article), but we added to the questionnaire some questions related to tenure security. We discussed tenure issues in greater detail in 18 group interviews and close to 100 interviews with key informants, including farmers, park rangers, NGO staff, and government officials.

The three research villages were Melaya, Penengahan and Negeri Ratu Ngaras (Fig. 1). Melaya consists of a core village near the coast, and two sub-villages in the uplands. In Melaya core village, Penengahan and Negeri Ratu Ngaras, the dominant land uses are damar agroforestry and wet rice cultivation, and most inhabitants are 'native' to the Krui-area. In the Melaya upland villages, located close to BBS National Park, inhabitants are predominantly Javanese migrants. Here coffee and pepper cultivation are the dominant land uses.

\section{Results}

\section{Land-cover Changes}

Over the whole Krui area the post classification comparison suggests that the area with mature agroforest increased by more than $10 \%$ between 1997 and 2002. Figure 2 presents the land-cover changes within the KdTI area. For $5 \%$ of the land-cover of the KdTI area in 1997 we have no data because of cloud cover. Since some mature agroforest may have been covered with clouds in the 1997 image, the 4\% increase of mature agroforest in 2002 may be overestimated. Although the figures need to be viewed with care due to the possibility of inaccuracies in the classification, we feel confident in our conclusion that the area under

\footnotetext{
${ }^{3}$ We conducted an accuracy assessment for the 2002 land-cover map, using 369 GPS reference points taken in 2005. The assessment showed an overall accuracy of $85 \%$, which includes real classification errors, locational uncertainty and actual land use changes between 2002 and 2005.

${ }^{4}$ To study livelihood dynamics we repeated a survey that was conducted in 1996 by Wollenberg and Nawir in three villages. The three research villages were selected to represent the three subdistricts of that time-North, Central and South Pesisir (Wollenberg et al., 2001; Wollenberg and Nawir, 2005).
} 
Fig. 1 Area covered by the satellite images and the location of the surveyed villages.

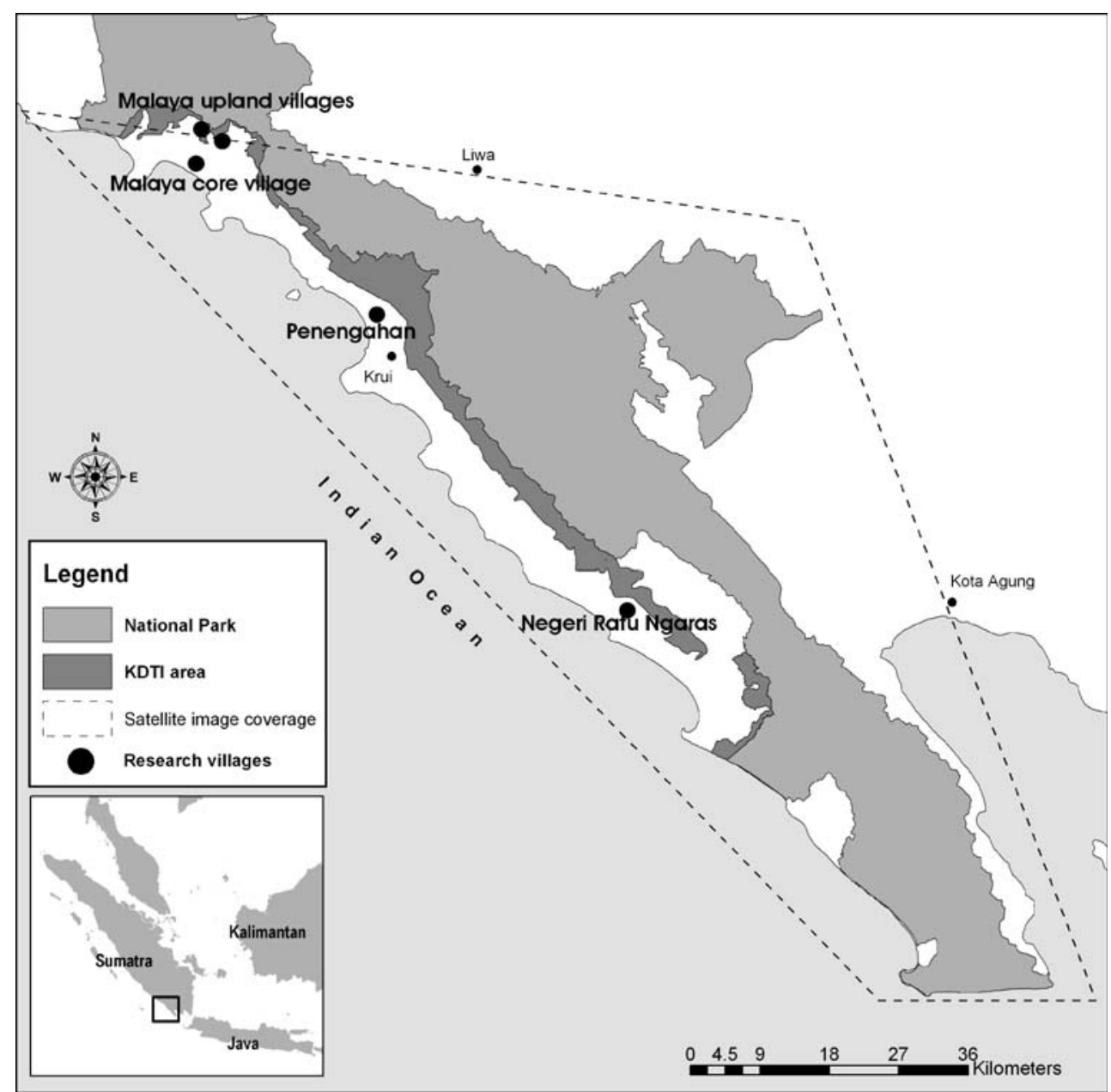

agroforest, both within and outside the KdTI area, has not decreased.

The images show small patches that seem to have evolved from coffee gardens in 1997 to more mature damar agroforest in 2002. Yet the 2002 image also showed small patches where mature agroforest seems to have been replaced with young coffee and pepper gardens. This suggests that the agroforests should be seen as dynamic systems.

Farmers, particularly in the southern part of the Krui region, confirmed that damar agroforests are sometimes converted. Conversion is stimulated by the increasing price for damar timber. Farmers also referred to the patches that are converted as being 'less productive.' There is a variety of possible reasons for low productivity:

(1) A lack of rejuvenation activities, i.e., a farmer does not plant damar seedlings regularly.

(2) Over-harvesting of resin producing trees. Too frequent harvesting affects the viability of the tree, for example making the tree susceptible to being blown over by the wind. Also, according to some farmers, too frequent harvesting negatively affects the long term resinproducing capacity of the tree.
(3) Some damar agroforests have never been intensively managed and should be interpreted more as fallows with a few damar trees - the damar trees were planted as a sign of ownership and their production is not economically viable. Such fallow systems are converted when the farmer is in need of agricultural land.

Farmers who cut down their agroforest plots are generally re-entering the first phase of establishing a new agroforest, i.e. dry rice fields, followed by coffee and/or pepper, mixed with tree seedlings.

Gaveau et al. (2005) found that $18 \%$ of the forest in BBS National Park was lost in 30 years (1972-2002), averaging $0.62 \%$ per year. Between 1997 and 2002 almost 16,000 ha of forest disappeared from the study area, of which 8,000 ha were located inside the National Park. Protection of the National Park was one of the implicit objectives of the KdTI decree. We therefore looked into the role of the agroforest in preventing further agricultural encroachment in the park.

Most of the deforestation occurred in the southeast and eastern part of the study area, far from mature agroforests (Fig. 3). The presence of agroforest seems to slow down encroachment, probably because it limits accessibility to the 
Fig. 2 Land-cover changes within KdTI area.

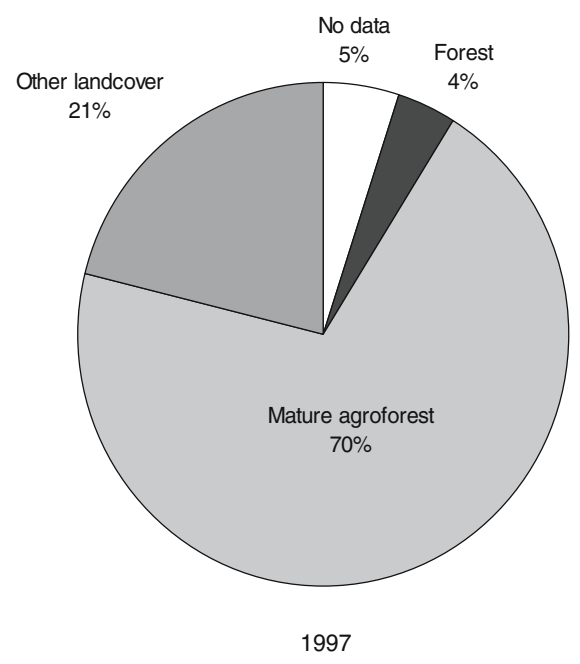

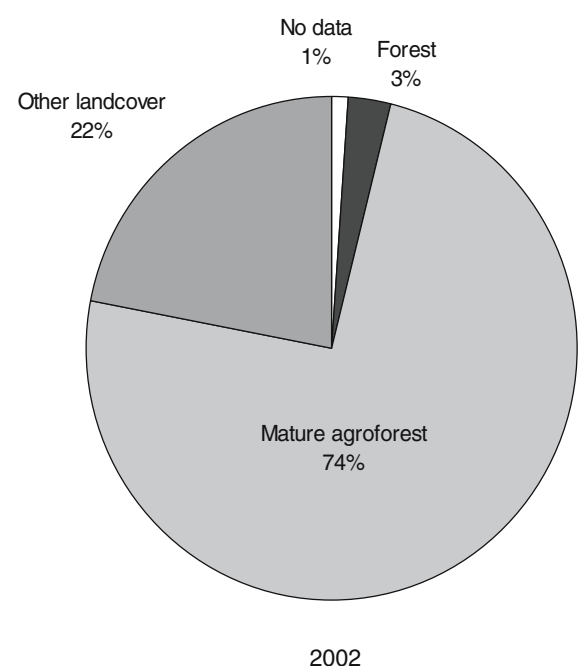

forest. The areas that are located on the east side of the agroforest belt are relatively difficult to reach and generally not accessible to motorized vehicles, except for heavy motorbikes with chained tires. The agroforest belt may thus play a role in reducing encroachment into the National Park. Having said that, our data also support the finding by Mary and Michon (1987) that the agroforest system by itself does not prevent encroachment. From the 2002 image we estimate that 7,500 ha of young coffee and pepper gardens have recently been established northeast of the agroforest massif, of which more than 1,000 ha are located inside the boundaries of the National Park. During in-depth interviews we learned that new lands are generally opened with the permission of a village leader, and that some village leaders are requesting payments in return.

Respondents in group interviews suggested that steepness of slopes and 'remoteness,' rather than presence of agroforest, are the main barriers for agricultural expansion. Gaveau et al. (2005), with their longitudinal study of forest loss in Southwest Sumatra, confirm that slope limits the conversion of forest land to agriculture.

\section{Local Perceptions of Land Status and Security}

In a household survey we recorded data for 811 agricultural fields, including mature damar agroforest plots. For each plot we asked the respondent (the 'owner') about the legal status. We then compared the status according to the respondents with the 'official status' derived from the land status maps of the Indonesian Forestry Department. ${ }^{5}$ The difference between official status and the status according

\footnotetext{
${ }^{5}$ We used the land status map that was produced by the Wildlife Conservation Society (WCS) and Lembaga Alam Tropika Indonesia (LATIN, a forest conservation oriented NGO) based on land status maps of the Indonesian Forestry Department.
}

to the respondents is most striking for the mature damar agroforest plots belonging to respondents from Penengahan (Fig. 4). The difference indicates lack of knowledge or lack of willingness to accept the government's claim on the part of the local respondents.

While virtually all respondents knew about the National Park and its boundaries, only $23 \%$ of the 296 respondents claimed to know the term HPT. ${ }^{6}$ It is possible that some respondents in the survey were aware of the state's claim, but not familiar with the term 'HPT.' In group and in-depth interviews, however, we did not come across such respondents. In these interviews we encountered three typical groups of respondents: (1) about $10 \%$ who knew about the term and have a clear understanding of the claim; (2) another $10 \%$ who indicated that they 'knew about' the term but were actually not well informed about its meaning; and 3 ) about $80 \%$ who neither knew about the term nor about the claim. In the Melaya upland villages, villagers' knowledge was relatively high (Table I) because there are concrete HPT boundary signs inside the respondents' coffee and pepper gardens.

Of the surveyed heads of households, only 3\% claimed to know about the KdTI decree. Soon after the signing of the decree, Tim Krui disseminated a short leaflet with the decree and an explanation. After that, however, the government failed to follow up, which may explain the current lack of awareness of the decree. As De Foresta (1999, unpublished data) indicates, the Ministry of Forestry may have been reluctant to implement the decree beyond the recognition of the distinctive status zone. Within the Ministry there had been opposition to the process of

\footnotetext{
${ }^{6}$ We did not ask explicitly about people's knowledge of the term HL (Hutan Lindung or 'protective forest') because the area under HL is relatively small.
} 
Fig. 3 Area under damar agroforest, natural forest cover and deforestation 1997-2002.

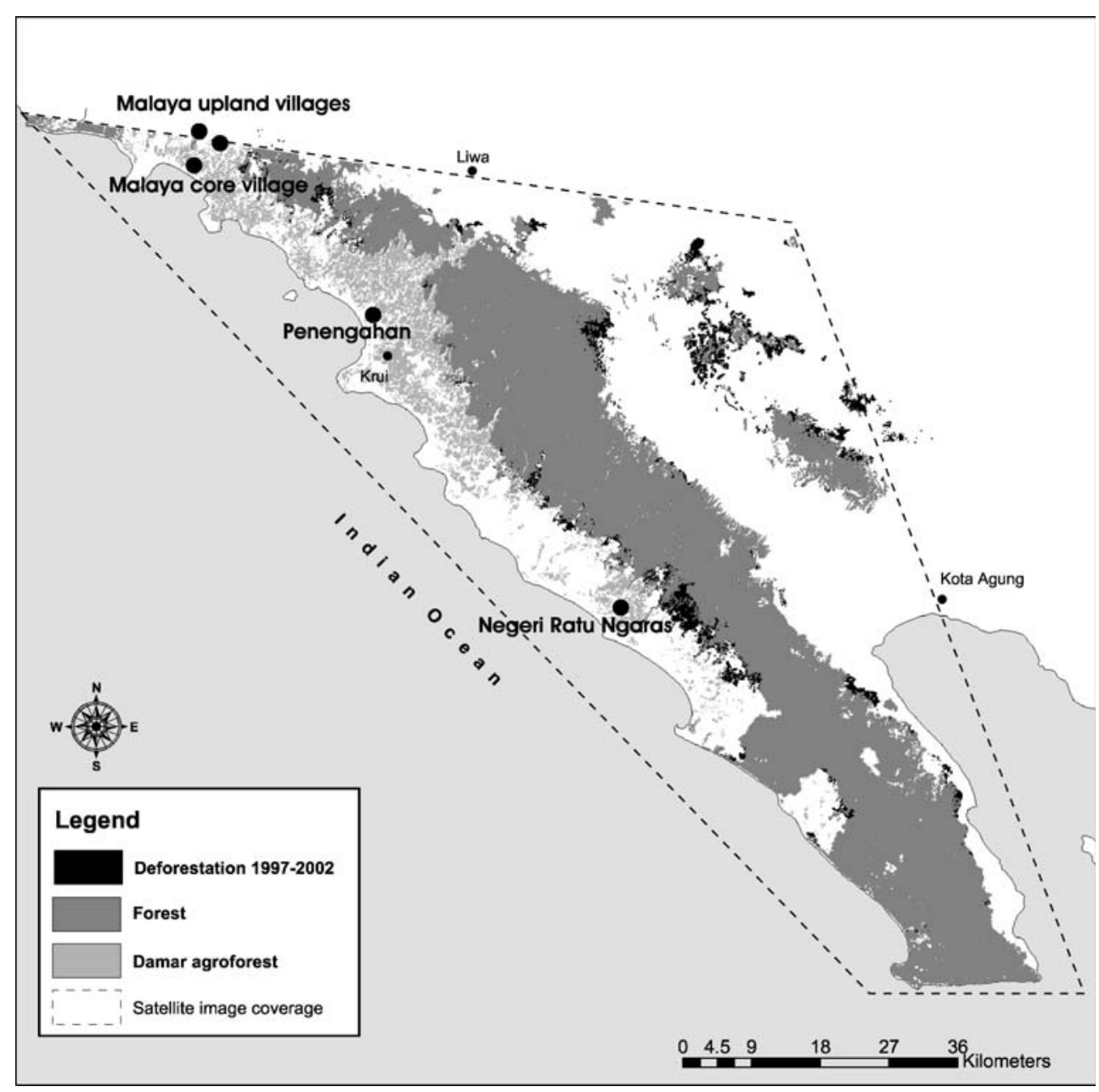

creating the decree (Fay and De Foresta, 2001). At the local level, forestry officers were not very supportive, as the decree would entail a reduction of their control over the management direction and benefits from the forest area. At a more central level, many high level officers were worried about reduction of control and feared that the KdTI-Krui precedent would result in more KdTI type decrees being issued for other contested state forest areas. This opposition

Table I Knowledge of Land Status

\begin{tabular}{lll}
\hline & $\begin{array}{l}\text { Heads of households } \\
\text { who know about HPT } \\
(\%)\end{array}$ & $\begin{array}{l}\text { Heads of households } \\
\text { who know about KdTI } \\
(\%)\end{array}$ \\
\hline $\begin{array}{c}\text { Melaya core } \\
\text { village }(n=45)\end{array}$ & 7 & 7 \\
$\begin{array}{c}\text { Melaya upland } \\
\text { villages }(n=73)\end{array}$ & 42 & 0 \\
$\begin{array}{c}\text { Penengahan } \\
(n=99)\end{array}$ & 16 & 3 \\
$\begin{array}{c}\text { Negeri Ratu } \\
\text { Ngaras }(n=79)\end{array}$ & 22 & 3 \\
Total $(n=296)$ & 23 & 3 \\
\hline
\end{tabular}

did not vanish after the issuance of the decree, which explains why local forest services did not actively disseminate information regarding the decree, and why they never encouraged the Krui community representatives to formally register their land use rights. During our study we found that the awareness of the decree had dissipated, not only at community but also at government level. Even senior forestry officials at district and province level — particularly the ones who had entered office after 1998-did not know or did not have a clear understanding of the decree.

Roth and Haase (1998) define land tenure security as: "the individual's perception of his/her rights to a piece of land on a continual basis, free from imposition or interference from outside sources, as well as the ability to reap the benefits of labour or capital invested in land, either in use or upon alienation" (Roth and Haase 1998, pp.1-2). We experienced difficulties in assessing the extent to which legal status influences farmers' perception's of security, as farmers whose lands are located in the state zone according to the map generally claimed not to be aware of the legal status of the land. In the survey we tried to address the issue in general terms, and asked respondents whether there is a difference in security between traditional (marga) territory 
Fig. 4 Disputed status of fields with damar agroforest in Penengahan.

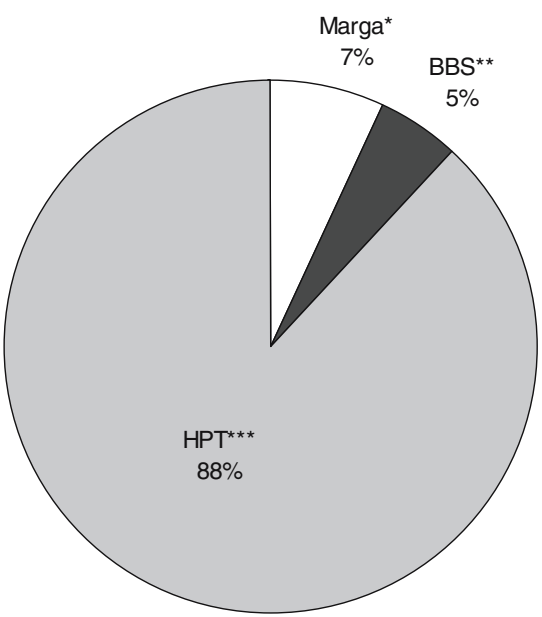

Status of Penengahan damar agroforest according to the government

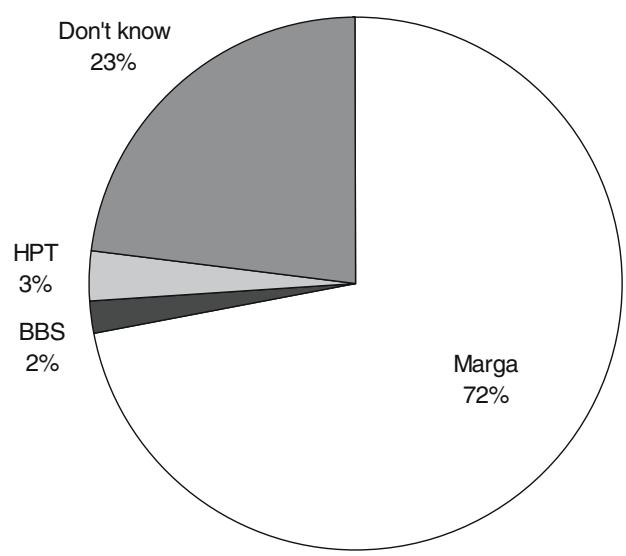

Status of Penengahan damar agroforest according to respondents

*Marga: Non contested traditional territory

${ }^{\star *}$ BBS: Bukit Barisan Selatan National Park

${ }^{* \star *}$ HPT: State Production Forest

that is officially recognized by the government and traditional territory that is not. Sixty percent of the respondents said that they 'did not know.' Thirty-four percent of the respondents answered that the level of security is higher when agricultural lands are officially recognized by the government, while $6 \%$ felt there was no difference.

During in-depth and group interviews we were able to discuss tenure security in greater detail. We addressed the following components: (1) whether or not farmers are confident that they will be able to reap benefits from the land, both in the short and the long term; (2) whether farmers feel threatened that their land may be encroached upon by outsiders; (3) whether lands are alienable; and (4) whether farmers are making long-term investments.

Regarding the first two components, farmers whose lands are effectively located in the HPT/HL zone, i.e., either within or outside the KdTI area, did not express insecurity, while the farmers with lands inside the National Park did. Regarding alienability of the lands, we found that transactions of lands that are located in the HPT/HL zone do take place, although not very regularly. According to respondents, the price of a field in the uplands - most of which are formally HPT/HL lands - tends to be between 50 and $75 \%$ of the price of a similar field in the lowlands, because of the greater distance to the village or road. Regarding the relation between tenure security and longterm investments we found a two-way relationship: Farmers with coffee and pepper gardens in the HPT/HL zone felt secure enough to plant damar and fruit trees in their fields, and that planting trees also increased the perception of security. Tree planting traditionally functions as a sign of ownership (see for instance Otsuka and Place, 2001). We found that the notion that tree planting secures the right to use the land has been strengthened through the influence of outsiders, as illustrated by the following quotes: "If we plant damar, the position of the community becomes stronger;" "The government will respect our lands if we plant damar, because it is rehabilitation without costs to the government;" "Planting damar increases the bargaining power, because planting of damar is backed up by NGOs;" and "By planting damar, our right becomes stronger." This is consistent with Niimura (2000) who studied migrant communities in the north of the Krui area and found that, with intensifying interventions from outsiders, there was a growing notion among farmers that the planting of damar trees secures land tenure.

Before 1998 the situation was strikingly different. Between 1995 and 1997 government officials entered the area to demarcate the boundary of the state forest zone by putting concrete poles in people's fields. The officials tried to reduce tension with farmers by claiming nothing would change in practice and that they had no reason to worry about their lands. During interviews in 2005, respondents recalled these claims, and confirmed that, indeed, little had changed. At the time, however, the demarcation activities created great unrest among village representatives and the farmers who were confronted with signs in their fields. Their feeling of security sank to a minimum when government officers entered people's agroforests to measure lands on behalf of an oil palm company. During these insecure times farmers who were aware of the threats 
postponed their plans to plant fruit and damar trees inside their young plantations due to their fear that they would be evicted (De Foresta 1999, unpublished data).

\section{Discussion}

Impact of the KdTI Decree

Under President Suharto's regime the political actors did not want to discuss transferring ownership over the lands in the HPT/HL zone back to the communities by withdrawing the HPT/HL status and moving the boundary of the state forest zone back to the National Park (De Foresta, 1999, unpublished data). In that political context, a decree that awarded user rights for state forest lands was probably the 'best possible' legal solution for the land conflicts in the area. The communities, however, saw the KdTI decree as negating their land ownership rights, because it still considered the land as state land. Soon after the decree was issued, a new political environment emerged with the fall of Suharto and the community leaders became increasingly reluctant to see the decree implemented. The communities hoped that the reform period would provide opportunities to reclaim ownership of the traditional territory, extending up to the boundaries of the National Park. Consequently, between 1998 and 2005 none of the Krui communities applied for their concession rights in the KdTI area.

As the decree was never fully implemented, i.e., no attempt was made to formally register community rights, we need to look at its impact in a wider context. We found that the process leading to the decree had been more important than the decree itself. The key milestone in the process towards the decree was the government's recognition that the damar agroforests are cultivated and managed sustainably by local communities. The KdTI decree is the formal representation of this recognition.

At the time of signing the decree, there were considerable threats to the damar agroforests located within the KdTI area. Firstly, an oil palm company was eager to open negotiations to expand oil palm plantations in the state forest zone. In the process of creating the decree, the government stopped its active support for oil palm expansion occurring at the expense of damar agroforests. This was the start of the restoration of farmers' feeling of security. The KdTI decree gave the government a formal argument not to facilitate oil palm expansion on state lands. Secondly, during the preparation phase of the KdTI decree, a proposal emerged to create a private company to manage the HPT forest lands for damar resin and timber. This forestry company would operate under the umbrella of a state-owned logging company, with a $40 \%$ share by a local farmers' cooperative. The proposal was dismissed because it was viewed as incompatible with the ideas that were being formulated in the KdTI decree (De Foresta 1999, unpublished data).

Notwithstanding the above-mentioned outside interests, since 1998 the government has not claimed or leased out the resources in the state forest zone. And, even though none of the communities applied for the concession rights, they have been allowed to reap full benefits from their activities in the state forest zone. As there have been no direct threats, farmers feel relatively safe on the lands from the coast up to the National Park - the lands that are being claimed as traditional territory.

In addition to the lack of direct threats, various other factors seem to play a role in determining the recent perception of security. First, many farmers have a limited understanding of the state's claim to begin with, and may thus have fields on state lands without actually knowing the legal status of their fields. Second, the traditional claim on the lands up to the National Park is strong. Many Krui communities feel 'empowered' in their dealings with the government, partly because communities can refer to 'scientific proof' that the agroforests have been planted. Third, after 1998, local government officials, being aware of the community's claim, have been tolerant towards any agricultural activity in the HPT/HL zone. Their passive behaviour has been instrumental in maintaining a status quo, in which farmers' de facto rights on the lands are not being challenged. Fourth, the Krui case became a high profile case because of the involvement of NGOs and research institutions. The involvement of these institutions not only strengthened the communities' confidence and helped to alter the government's attitude towards the area, but also ensured plenty of media attention.

\section{The Future}

While farmers feel relatively safe and the government respects local land use in the HPT/HL zone, the status quo seems fragile. There is a risk that conflicts between the state and local communities will reemerge. In the Krui region land available for agriculture is becoming scarcer. And, with the post December 2004 Tsunami scare influencing villages directly on the coast, one can expect pressure to move further inland. Consistent with Contreras-Hermosilla and Fay (2005), who state that tenure arrangements become more important with increasing land scarcity, increased competition for lands in the Krui region may revitalize the debate on the (lack of) community ownership rights. Also, decentralisation, making district authorities responsible for most governance within their area and for developing their own sources of financing, could act as an incentive for district governments to accelerate exploitation of state 
forest lands to raise revenue. The boundary between 'legal' and 'illegal' logging is unclear where different levels of government have different interests (Obidzinski, 2005). During our field research in 2005, there were rumours of negotiations between the district government and timber plantation and oil palm companies. Considering the lack of official registration of lands under the KdTI decree and the eroded awareness of the decree at government as well as community level, such rumours may become real threats in the future. The question would then be whether communities are able to effectively use the KdTI decree to prevent appropriation by companies.

The current decentralized political context offers opportunities as well as threats. The district government seems better positioned and willing to respond to local needs and there may be opportunities for the communities to open negotiations to improve their legal situation. ContrerasHermosilla and Fay (2005) suggest the Krui region is suitable as a test case for further tenure reforms. Fathullah et al. (2005) documented recent experience elsewhere in West Lampung with formal excision of land from the state forest zone. Case studies of locations where situations similar to Krui are still waiting for solutions are described by Galudra et al. (2005) and Sirait et al. (2005).

The coastal zone of West Lampung has some characteristics - the KdTI experience, strong and clear customary tenure regulations, scientific backup of traditional claims, 'empowered' local communities and the presence of NGOs - that may increase the chance of success of future tenure reforms. A few respondents mentioned the possibility of negotiating a deal with the district government. They said communities would be willing to commit to maintaining the agroforest and preventing further encroachment if they received community ownership of the lands up to the National Park in return. However, even though decentralisation has given greater autonomy to the district, actual transfer of ownership of lands within the state forest zone would require the political will of the central government in Jakarta as well.

\section{Conclusions}

The decree with which the Indonesian government recognized the sustainable local management of agroforests located within the Krui state forest zone was meant to provide farmers with enough security to continue their agroforestry activities. Implicitly, the decree also meant to protect the National Park by maintaining a buffer area. We found that in contrast with farmers of the mid 1990s, farmers in 2005 feel relatively secure and continue making investments in agroforestry systems within the state forest zone. Analysis of satellite images of before and after the decree suggests that the area of agroforest within the state forest zone has been maintained. Also, while the agroforest production system does not by itself prevent encroachment, to a certain extent the agroforest belt functions as a buffer zone, which is related to its lack of roads and tracks for motorized vehicles and the distance it imposes from the village to the forest. The decree thus seems to be successful. The relation between the decree, tenure security, and the maintenance of the agroforest system is, however, not as straightforward as it seems.

The Krui communities were cultivating lands with their agroforest system for more than a century before those lands became classified as state forest lands. They therefore have a strong and longstanding ownership claim on these lands. The policy change that was meant to provide the farmers with legal user rights was signed right before a period of rapid political change. In the post-Suharto era, only a decree that recognizes ownership is acceptable to the communities. None of the local communities ever registered for concession rights in the KdTI area, as this would have implied recognition of state ownership of the land.

While the KdTI decree does not represent a de jure change in tenure regime, the recognition of the local rights in the KdTI decree with the designation of the distinctive use zone has de facto safeguarded the agroforest from claims by outsiders. The decree represented the state's recognition of both the sustainability of local land-use as well as the rights of users to maintain and benefit from the land-use system they developed on the contested land. This recognition changed the government's approach to the 'development' of the state forest zone and proved efficient in relieving the pressure of appropriation of the disputed land by outsiders and in allowing local users to continue their land-use system. Impacts of the decree should thus be seen in terms of prevention of change, rather than change.

The Krui experience helps to nuance the widely accepted idea that farmers without legal tenure rights lack the incentives to make long-term investments in sustainable management of natural resources. We encountered a paradoxical situation where farmers feel relatively secure on their lands, even though the process that would provide them with legal user rights was never completed. We conclude that the perception of tenure security is not necessarily related to the legal status of the land. The perception of security is influenced by a range of factors: the existence of direct threats; the awareness of the legal status; the strength of the traditional claim; the existence of external support; and the role of local government officials.

In the study villages the perception of security is sufficient for farmers to make long-term investments in complex agroforestry systems. At the same time, messages from the outside world have stimulated the development of tree-based systems as a strategy to increase security. Indeed, 
it could even be argued that the lack of legal security in some cases promotes tree planting.

The question of ownership of forest lands is a sensitive one in many countries, and conflicts between the state and local users' communities over forestland are on the rise in Indonesia as elsewhere in the tropics. These conflicts need mitigation as they may have detrimental socioeconomic consequences for local communities and may negatively affect the sustainability of forest land management. The KdTI decree, based on the recognition of local communities as the only legitimate managers of a given area of state forest, is an original attempt to mitigate such conflicts. To local communities, such a solution helps to ensure protection against outsiders, while guaranteeing the full benefits of their work-as long as their land use system stays compatible with 'forest functions.' To the state, the value of such a solution lies in its intermediate status, between full recognition of land ownership rights and exclusion of local users from the disputed land, allowing the state's forest services to influence the management orientation of the area. The KdTI decree has been successful in reaching its objectives, i.e., improving security and maintaining the agroforest area under community management. The KdTI experience therefore provides important lessons that should be taken into account in the design of solutions for statecommunity conflicts elsewhere in the tropics.

Acknowledgements The study was financially supported by CIFOR and ICRAF. The study is part of a $\mathrm{PhD}$ research funded by the University of Amsterdam. The basic GIS data and the 1997 satellite image that were used for the land-cover analysis are property of WCS. The 2002 satellite image was provided by WWF. Atiek Widayati and David Gaveau provided support to the spatial analysis. Philip Manalu was invaluable during fieldwork and analysis of the survey data. We thank LATIN, WALHI, LPSd Beguai Jejama, YBWS, and PMPRD for assisting the fieldwork. And we thank Marcus Colchester, Mirjam Ros-Tonen, Patrice Levang, Trudy O'Connor and three anonymous reviewers for their comments on earlier versions of the paper.

\section{References}

Acheson, J. (2000). Clearcutting Maine: Implications for the Theory of Common Property Resources. Human Ecology 28(2): 145-169.

Brasselle, A-S., Gaspart, F., and Platteau, J-P. (2002). Land Tenure Security and Investment Incentives: Puzzling Evidence From Burkina Faso. Journal of Development Economics 67: 373-418.

Contreras-Hermosilla, A., and Fay, C. (2005). Strengthening Forest Management in Indonesia Through Land Tenure Reform: Issues and Framework for Action, Forest Trends, Washington, DC.

De Foresta (1999). "Tim Krui" Consortium: CBSFM program. Grant no 950-1510: October 1995-September 1998. Final report to the Ford Foundation.

De Foresta, H., and Boer, E. (2000). Shorea javanica Koord. \& Valeton. In Boer, E., and Ella, A. B. (eds.), Plant Resources of South-East Asia. no. 18: Plants Producing Exudates, Backhuys Publishers, Leyden, pp. 105-109.

Ekadinata, A., Kusters, K., Widayati, A., Gaveau, D., and Aslan (2005). Landcover dynamics in West Lampung, Sumatra,
Indonesia, Technical report submitted for ICRAF Internal Workshop: Impact Study of ICRAF Land and Tree Tenure Programme, Bogor, 1-2 August 2005. World Agroforestry Centre-ICRAF, SEA Regional Office. [online] URL: http:// www.worldagroforestry.org/sea/Publications/searchpub.asp? publishid $=1283$.

Enters, T., Durst, P., and Brown, C. (2003). What does it take? The role of incentives in forest plantation development in the AsiaPacific Region, UNFF intersessional experts meeting on the role of planted forests in sustainable forest management, 24-30 march 2003, New Zealand. [online] URL: http://www.maf.govt. $\mathrm{nz} / \mathrm{mafnet} /$ unff-planted-forestry-meeting/conference-papers/roleof-incentives-in-forest-plantation.pdf.

FAO (2005). Global Forest Resources Assessment 2005: Progress towards sustainable forest management, FAO Forestry Paper 147, Rome. [online] URL: http://www.fao.org/docrep/008/a0400e/ a0400e00.htm.

Fathullah, Situmorang, L., Cahyaningsih, N., Nuch, I., and Sirait, M. (2005). Perubahan status kawasan hutan guna memjawab permasalahan kemiskinan dan ketahanan pangan: studi kasus dari marga Bengkunat dan pekon Sukapura, Kabupaten Lampung Barat. In Tanah Masih Di Langit, penyelesaian Masalah Penguasaan Tanah dan Kekayaan Alam di Indonesia yang Tak Kunjung Tuntas di Era Reformasi, (ISBN 979-97910-5-7), Yayasan Kemala, Jakarta, pp. 619-630.

Fay, C., and De Foresta, H. (2001). Progress towards recognising the rights and management potentials of local communities in Indonesian State-defined forest areas. In Vira, B., and Jeffery, R. (eds.), Analytical Issues in Participatory Natural Resource Management, Palgrave, Basingstoke, pp. 185-207.

Fay, C., and Michon, G. (2005). Redressing Forestry Hegemony: When a Forestry Regulatory Framework is Best Replaced by an Agrarian One. Forests, Trees and Livelihoods 15: 193-209.

Fay, C., De Foresta, H., Sirait, M., and Tomich, T. P. (1998). A Policy Breakthrough for Indonesian Farmers in the Krui Damar Agroforests. Agroforestry Today 10(2): 25-26.

Fearnside, P. M. (1989). Extractive Reserves in Brazilian Amazonia. BioScience 39(6): 387-393.

Fearnside, P. M. (2001). Land-tenure Issues as Factors in Environmental Destruction in Brazilian Amazonia: The Case of Southern Pará. World Development 29: 1361-1372.

Forestry Planning Agency (2004a). Vegetation Coverage of Forest Area by Province Up to Year 2003. [online] URL (accessed on December 6, 2004): http://www.dephut.go.id/INFORMASI/ STATISTIK/Stat2003/Baplan/IV1202.pdf.

Forestry Planning Agency (2004b). Forest Area Based on Decree of Minister of Forestry. [online] URL (accessed on December 6, 2004): http://www.dephut.go.id/INFORMASI/STATISTIK/ Stat2003/Baplan/IV1102.pdf.

Galudra, G., Ramdhaniaty, N., Soenarto, F., Nurzaman, B., and Sirait, M. (2005). Kondisi ketahanan panagn masyarakat dalam cengkeraman bebijakan tata ruang dan penetapan kawasan Halimun: Studi kasus desa Mekarsari (Lebak) dan desa Malasari (Bogor). In Tanah Masih Di Langit, penyelesaian Masalah Penguasaan Tanah dan Kekayaan Alam di Indonesia yang Tak Kunjung Tuntas di Era Reformasi, (ISBN 979-97910-5-7), Yayasan Kemala, Jakarta, pp. 653-674.

Gaveau, D. L. A., Wandono, H., Setiabudi, F., Aslan (2005). Three Decades of Deforestation in Southwest Sumatra: did Protected Areas Halt Forest Degradation and Facilitate Regeneration? Wildlife Conservation Society Report, Bogor.

Godoy, R., Jacobson, M., De Castro, J., Aliaga, V., Romero, J., and Davis, A. (1998). The Role of Tenure Security and Private Time Preference in Neotropical Deforestation. Land Economics 74(2): 162-170.

Kumar, S. (2002). Does "Participation" in Common Pool Resource Management Help the Poor? A Social Cost-Benefit Analysis of 
Joint Forest Management in Jharkhand, India. World Development 30: 763-782.

Lubis, Z. (1996). Repong damar: kajian tentang proses pengambilan keputusan dalam pengelolaan lahan hutan di Pesisir Krui, Lampung Barat, M.Sc. Thesis, Universitas Indonesia, Jakarta.

Lynch, O. J., and Talbott, K. (1995). Balancing Acts: Communitybased Forest Management and National Law in Asia and the Pacific, World Resources Institute, Washington, DC.

Mary, F., and Michon, G. (1987). When Agroforests Drive Back Natural Forests: A Socio-economic Analysis of a Rice-Agroforest System in Sumatra. Agroforestry Systems 5: 27-55.

MoF (1998). Decree of Minister of Forestry No. 47/Kpts-II/1998 Concerning the Designation of $+/-29,000$ Hectares of the Protective Forest and Limited Production Forest Zone, From the Pesisir Forest Grouping, in West Lampung District, Province of Lampung, which are Covered by Damar Agroforests ('Repong Damar') Managed by Communities under Customary Law (Masyarakat Hukum Adat), as a Zone with Distinct Purpose (Kawasan Dengan Tujuan Istimewa).

Michon, G. (2005). Domesticating Forests-How Farmers Manage Forest Resources, IRD, CIFOR and ICRAF, Bogor.

Michon, G., and De Foresta, H. (1995). The Indonesian agroforest model. Forest resource management and biodiversity conservation. In Halladay, P., and Gilmour, D. A. (eds.) Conserving Biodiversity Outside Protected Areas. The Role of Traditional Agro-Ecosystems, IUCN, Gland, pp. 90-106.

Michon, G., and De Foresta, H. (1999). Agro-forests: incorporating a forest vision in agroforestry. In Buck, L. E., Lassoie, J., and Fernandes, E. C. M. (eds.), Agroforestry in Sustainable Agricultural Systems, CRC LLC, Boca Raton, FL, pp. 381-406.

Michon, G., De Foresta, H., Kusworo, and Levang, P. (2000). The damar agroforests of Krui, Indonesia: justice for forest farmers. In Zerner, C. (ed.), People, Plants and Justice: The Politics of Nature Conservation, Columbia University Press, New York, pp. 159-203.

Niimura, Y. (2000). Knowledge, Social Dynamics and Damar Agroforests: the Role of Outsiders in Promoting Sustainable Local Resource management in Pesisir Krui, Indonesia, MA Thesis, Wye College, University of London, London.

Obidzinski, K. (2005). Illegal logging and the fate of Indonesia's forests in times of regional autonomy. In Tanah Masih Di Langit, penyelesaian Masalah Penguasaan Tanah dan Kekayaan Alam di Indonesia yang Tak Kunjung Tuntas di Era Reformasi, (ISBN 979-97910-5-7), Yayasan Kemala, Jakarta, pp. 429-449.

Otsuka, K., and Place, F. (eds.) (2001). Land Tenure and Natural Resource Management: A Comparative Analysis of Agrarian Communities in Asia and Africa, John Hopkins University Press, Baltimore, MD.

Pagdee, A., Kim, Y., and Daugherty, P. J. (2006). What Makes Community Forest Management Successful: A Meta-study From Community Forests Throughout the World. Society and Natural Resources 19(1): 33-52.

Peralta, P., and Mather, P. (2000). An Analysis of Deforestation Patterns in the Extractive Reserves of Acre, Amazonia from Satellite Imagery: A Landscape Ecological Approach. International Journal of Remote Sensing 21: 2555-2570.
Roth, M., and Haase, D. (1998). Land Tenure Security and Agricultural Performance in Southern Africa, BASIS Southern Africa Program publication, Land Tenure Center, University of Wisconsin-Madison, Madison. [online] URL: http://www.ies. wisc.edu/ltc/live/bassaf9806a.pdf.

Safitri, M. A., (2005). Tenure security, sebuah arena pluralisme hukum di kawasan hutan negara. In Tanah Masih Di Langit, penyelesaian Masalah Penguasaan Tanah dan Kekayaan Alam di Indonesia yang Tak Kunjung Tuntas di Era Reformasi, (ISBN 979-97910-5-7), Yayasan Kemala, Jakarta, pp. 269-276.

Schlager, E., and Ostrom, E. (1992). Property Rights Regimes and Natural Resources: A Conceptual Analysis. Land Economics 68: 249-262.

Sirait, M., Williams, S. E., Van Noordwijk, M., Kusworo, A., Budidarsono, S., Tomich, T. P., Suyanto, S., Fay, C. M., and Thomas, D. P. (2001). Policy Research for Sustainable Upland Management. ASB_LN 12. In Van Noordwijk, M., Williams, S. E., and Verbist, B. (Eds.), Towards Integrated Natural Resource Management in Forest Margins of the Humid Tropics: Local Action and Global Concerns. ASB-Lecture Notes 1-12, International Centre for Research in Agroforestry (ICRAF), Bogor. Also available from: http://www.worldagroforestrycentre.org/sea/Products/Training/ modules.asp.

Sirait, M., Bulor, D. B., Sofyar, Y., Anugrah, D., Rismawan, R., and Suyradin, D. (2005). Refleksi pengembangan metodologi identifikasi masyarakat adat dan wilayah adat secara partisipatif di kabupaten Kutai Barat, Kalimantan Timur. In Tanah Masih Di Langit, penyelesaian Masalah Penguasaan Tanah dan Kekayaan Alam di Indonesia yang Tak Kunjung Tuntas di Era Reformasi, (ISBN 979-97910-5-7), Yayasan Kemala, Jakarta, pp. 675-698.

Suyanto, S., Tomich, T. P., and Otsuka, K. (2001). Land Tenure and Farm Management Efficiency: The Case of Smallholder Rubber Production in Customary Land Areas of Sumatra. Agroforestry Systems 52: 145-160.

Tomich, T. P., Thomas, D. E., and Van Noordwijk, M. (2004). Environmental Services and Land-Use Change in South-East Asia: From Recognition to Regulation or Reward? Agriculture, Ecosystems and Environment 104: 229-244.

Torquebiau, E. (1984). Man-made Dipterocarp Forest in Sumatra. Agroforestry Systems 2(2): 103-128.

Van Goor, C. P., and Kartasubrata, J. (Eds.) (1982). Indonesian Forestry Abstracts, Dutch literature until about 1960, Centre for Agricultural Publishing and Documentation, Wageningen.

White, A., and Martin, A. (2002). Who Owns the Worlds Forests? Forest Tenure and Public Forests in Transition, Forest Trends, Washington, DC.

Wollenberg, E., and Nawir, A. (2005). Turning Straw into Gold: Specialization Among Damar Agroforest Farmers in Pesisir, Sumatra. Forests, Trees and Livelihoods 15(4): 317-336.

Wollenberg, E., Nawir, A., Uluk, A., and Pramono, H. (2001). Income is Not Enough: The Effect of Economic Incentiveson Forest Product Conservation-A Comparison of Forest Communities Dependent on the Agroforests of Krui, Sumatra and Natural Dipterocarp Forests of Kayan Mentarang, East Kalimantan, Center for International Forestry Research (CIFOR), Bogor 